\title{
Health, Piety and Peace by Spirit, Ayurveda, Modern Yoga \& Science
}

\author{
RAVI S PANDEY ${ }^{1,2, *}$ \\ ${ }^{1}$ World Health Piety and Peace Center, Panch Nibia-Shesh Ke Pura-Belvan Padari Mirzapur, India \\ ${ }^{2}$ Mahima Reasearch Foundation \& Social Welfare, BHU Varanasi \\ *Corresponding author: dr.rspandey@yahoo.com
}

Received April 12, 2014; Revised May 09, 2014; Accepted May 15, 2014

\begin{abstract}
Wise men of intellects know that the materialistic human body is genetically controlled, environmentally modulated and controlled by unknown deluding power (Maya) or ULTIMATE. In the current period of time, Lust, Anger, Greed, Pride, Jealous, duplicity, perversity, hypocrisy, malice, heresy, pride, infatuation, concupiscence and arrogance pervade the whole universe. All are unreal, even though remedy is unknown. In this presidential address, I am bringing the new insights of these invisible agents and their remedies in association with diseases of mind, brain and body to provide complete health, doctrine and peace to whole world. The available unfathomable universe (Spirit, Piety, Vedas, Puranas, Agamas, Modern Yoga and Science) has been churned out in the laboratory of Nature and nectar like medicine has been discovered in the form of Ayurvedic, Yoga, Devotion, Wisdom and Dispassion. In brief, the root cause of diseases is the unreal concept of universe that is duality. Where is duality? In real fact, this does not exist and we all are just sleeping in night of delusion. All the human beings are bound to live their life under three humors "Sattva, Rajas and Tamas" and three states "Awaken, Dream and Sound Sleep" under the management of nature as slave of Desire, Senses \& Mind. Indeed, all are suffering by time; fate; merit; demerit or disposition, but exact reason is unknown. In this, my approach is to bring the hypothesis of evenness theory in scientific society as the time is constant, only the dangerous waves of ignorance are flowing in the current period of time in all over universe. Under steeped condition, I and other have studied the level of DNA, RNA and Protein that is visible. Thus, we believe science with complete confidence and faith. Is there any remedy available to eradicate these invincible factors of diseases? Yes! Interestingly, in the laboratories of Nature, I have developed the remedies for these invincible factors along with an Ayurvedic formulation for the treatment of Vitiligo. Considering the very limit of Nescience and tremendous grief of whole universe, I have worked little hard to developed some nectar type medicine and in stage to reframe the universe by providing Health, Doctrine \& Peace.
\end{abstract}

Keywords: Health, Piety, Peace, Spirit, Ayurveda, Modern Yoga \& Science

Cite This Article: RAVI S PANDEY, "Health, Piety and Peace by Spirit, Ayurveda, Modern Yoga \& Science.” American Journal of Biomedical Research, vol. 2, no. 2 (2014): 19-28. doi: 10.12691/ajbr-2-2-2.

\section{Introduction}

With absolute confidence, I took the charge to eradicate all the disease of mind brain and body and luminaries the globe by establishing the peaceful world in next $20 \mathrm{y}$. I shall endeavor to hold the great traditions of the goal. I have been participating in the welfare of the society for more than twenty one years at different capacities like a Pool Scientist, Distinguished Scientist and now as the Director and President of World Heath Piety \& Peace Center (WHPPC). Let us start; the origin of thought, word and deed is basically dependent upon the environment in which a creature lives. The environment constitutes elements blowing in the form of winds and waves and affecting three forms of state of body (Awaken, Dream and Sound sleep) and moods/ prakriti (Divine, Human and Demon/ Sattva, Rajas and Tamas) as described in Ayurveda. The derangement of these three caused birth of diseases of the mind and body, that is invisible and beyond assumption and realization under these state and mood of mind and body. Indeed, everybody suffers, but very rare people realize to some extent. Thus, no one took the charge of these from thought, word and deed, as problems still exist. In the vision of Vedas, Puranas, Religious scriptures and me, all are under the influence of invincible factors of deluding potency 'Ignorance' and its generals and councilors and innumerable armies. The mysterious potency of deluding power could be resolve and establishment of happy and peaceful world in the next 20 years is absolutely possible with the help of Spirit, Devotion, Wisdom, Doctrine, Vedas, Puranas, Agamas, Modern Yoga and Science. Considering the tremendous sorrows and grief of whole world and the value of old religious scripture, I have taken the charge of director and president to profess the whole word for ultimate welfare that is peace.

Let us start with basic; in human body, Mind is Universe, laden with Inordinate-Greed. This is originated from Desire as the demand of Senses. Instead of the command of invisible pure absolute soul, people are 
obeying the Mind. I consider; this is because of Ignorance. Is there any devise available that can develop pure mind under Ignorance? Thus, frankly writing, I did not find even a single man of wisdom in whole world, even in USA. I have concluded that is whole world is under the slave of Senses, Desire and Mind. Then, I started working directly with nature aloof from the world in Transcendent State of Mind. The state could be attained only by quietism of worldly attachment. Under this state of mind, I have seen that people around the globe are partially or fully steeped in IGNORANCE. In fact, this is unreal even though it has most valiant three generals Viz: Lust, Anger and Greed along with three councilors i.e. Pride, Jealous and Infatuation. All these are six impurities of materialistic body unnecessarily, people have cultured and the growth of progeny are pervading in the whole universe in the form of doubts, duplicity, perversity, hypocrisy, malice, heresy, concupiscence and arrogance and acting as armies. I encourage the audience and reviewer by informing that Remedies of Ignorance in the form of Wisdom is Absolutely available.

Each of honorable predecessors had delivered their presidential address on a specific theme throughout the world since long time; I too will like to do the same in unique way and strictly for only ultimate human welfare that is 'Peace'. The theme of my address is "Health, Piety and Peace by Spirit, Ayurveda, Yoga \& Science". Although, the objectives seem to be impossible, but dear reviewer! Mind it that the word 'possible' is hidden in it. The study has been carried out under the laboratory of Nature under pure, limpid and transcendental state of mind. In this study, the invincible factors have been discovered against deluding potency that is beyond the reach of the science of ignorance (Nescience). During my stay in United State, I was able to study the role of Antisense oligos in prevention of alternative splicing in Spinal Muscular Atrophy (SMA). This genetic disease is caused by single mutation (Pandey, 2013). A novel mixture of oligos was developed (Singh et al, 2010). In an independent study, I have analyzed all the 48,804 human genes known in the literature (Choudhary et al., 2010). Even though, we could not hope about the invincible factors by genetics and molecular level. Therefore, it was the need of whole universe to think beyond the genetics and molecular biology. I do not feel any sorry to write; "It is really a matter of shame for all of us that even knowing that all are made up of the same elements of universe, even though, we have a vision of duality, because of our ignorance only". Under this state I simply want to arise a simple concern 'Where is duality?' All the men of intellects are absolutely free to organize a meeting with immediate effect, collect the remedies and distribute throughout the world and thus, enjoy the real happy and peaceful life as soon as people want, by teaching the realm of human birth, wisdom and all that I already described. Thus, this is my sincere alertness to get aware all the people around the globe that all of you are imbued in unreal ignorance and it associates as described above. As a follower of spirit, I was able to prevent the maximum such impurities in my life except Anger and worldly attachment. Now, these two invincible army factors of ignorance, also wiped away by my sincere approach and God grace (Reference letter by adept). That inspired me to take the charge to pull out the entire universe from the night of delusion. At this stage, it's my humble request to reviewer to not allow their mind in pride.

Under the influence of these invincible causes, diseases of mind directly make a grip and affect the immune system of the people causing susceptibility of pathogens. At this stage people are compelled to face the diseases, woe and grief. Infatuation, which is the root of all ailments and from these again arise many other troubles. In brief, ignorance of Mineness causes the origin of Lust that is a counterpart of Inordinate-Greed and corresponds to an abundance of Phlegm/ Kapha; while Anger represents Bile/Pita, which is responsible for the entire digestive and metabolic functions; which constantly affect the heart. The cravings for the manifold pleasures of the sense, so difficult to realize, are the various distempers. Grudging contemplation of other's happiness represents Consumption; while Wickedness and Perversity decreases the immune strength, and people become more prone to pathogens. Egotism is a counterpart of the most painful Gout (clotting of blood vessels); while Hypocrisy, Deceit, Arrogance and Pride correspond to the disease known as Dracontiasis. Thirst for enjoyment represents the most advanced type of Dropsy; while the three types of craving (those for progeny, riches and honor) correspond to the violent quartan ague. Jealousy and thoughtlessness are the two types of fever, which are progenitor of Duplicity and Concupiscence that is the root cause of innumerable disorders of mind, ultimately reduces human life span (Quick ageing).

The solution of several such a potential invincible problems is absolutely available with me. As exception is always exists in almost every system, I lived a real human life for 39 years without Greed, Lust, Arrogance, Infatuation, Deceit, Pride and Concupiscence with complete purity, transparency and honesty (People around the globe are witnesses and proofs). In pure and true sense of my perceptions and inference after a thorough study of plenty of subjects like basic science, biochemistry, biotechnology, molecular biology, Ayurveda, spiritual study of different scriptures for a period of more than 21 years as an independent person, the origin of this study and proposal came out for the ultimate human welfare of society. Broader questions of the long term effects of these traits on mental disorder remains unanswered till the date. Upon implementation of Doctrine and Health the world will be free from all the sins, diseases of mind and body and ultimately demonic traits could be wiped out and people will live happy and peaceful life as a true sense of human birth. Through this note, I have opened my vision and mission of my rest of the life. I found that no one on this earth is even able to realize the level of problem as sins are growing day by day without any break. I promised to resolve the mystery of complication and disorders in order to provide real peace to the world. I, not only hypothesized even ready for eradication of maximum of such dangerous traits by systematic development of human brain and mind via doctrine of human life, wisdom, devotion, ayurveda, yoga and spirit and modern science together. My laboratory is woods (forest) consisting of Banyan, Neem and Peepal trees. Spiritual thoughts, words and deeds along with complete ayuvedic and yogic life style are known to be reverted winds and waves of the environment (Tulsidas, 1566 ), where all the creatures can alive with complete freedom and peace. Thus, using the 
doctrine of modern science, ayurveda, yoga and spirit, eradication of the root cause of numerous diseases of mind 'Infatuation' along with its associates like Lust, Anger, Greed, Arrogance and jealousy of demonic man can be transformed into the right direction of divinity and humanity and ultimately towards the peace.

It is thus high time, I put this occult phenomenon of spiritualism to the scrutiny by modem science and study it systematically, utilizing our knowledge and advances made in various physical sciences, neurosciences including neurophysiology, cybernetics and other fields. Scientific understanding of spiritualism may enlighten us on those various issues of day to day concern to every curious mind, including the phenomenon of life after life. It may provide holistic approach in improving the mental health care for the afflicted, preventive \& promotive mental health gains to the individuals improving the family ties. Restoring better social order, it may benefit the all nations \& humanity at large at global plane. Let us now examine the relevant issues in detail:

\section{Waves Flowing Around the Globe}

In the scenario of world development the Kaliyuga is the "Age of Downfall", that is the fourth stage. The corruption gradually developed wider in the earlier stages. This stage is the climax stage when the world finally meets a judgment day at the end of it as said in Hindu Scriptures. It's not known when the end comes, but it's believed that we still have a long way to go. Indeed it is terrible and assumed to be much more in future. Thus, I have initiated the research keeping myself aloof from world. I like to get aware all in my presidential address the true description story after my own experience of more than twenty (20) years of independent life in this birth. I like to narrate the truth in sweet and gentle words imbued with the nectar of greatest wisdom, dispassion and devotion. As no one is a source of delight or pain to another; everyone reaps the fruit of one's own actions. I am describing a few peculiars of waves of this age for ultimate human welfare. Please, do not pardon me if I will be found to be wrong. Review this real note with complete wisdom, dedication and devotion. Almost every man and woman is given over to sin. Every virtue has been engulfed by the sins of Kali; all good books have been almost disappeared; impostors had promulgated a number of creeds which people had invented out of their own wit. The people have been fallen a prey to delusion and all pious acts have been swallowed by greed. No one follows the duties of one's own doctrine, and the four stages (Ashram) of life also disappear. Every man and woman takes delight in revolting against the founder science known as Vedas. The kings are bleeding their subjects; no one respects the injunction of the Vedas. The right course for every individual is that which one takes a fancy to; a man of erudition is he who plays the braggart. Whoever launches spurious undertakings and is given over to hypocrisy, him does everyone call a saint like Asha Bapu a well known person as a world preceptor. He alone is clever, who robs another of his wealth; he who puts up false appearances is an ardent follower of established usage. He who is given to lying and is clever at joking is spoken of as a man of parts in this age. He alone who is a reprobate and has abandoned the path of the Vedas is a man of wisdom and dispassion in this age. He alone who has grown big nails and long locks of matted hair is a renowned ascetic in this age. They alone who put on an unsightly garb and ornaments, eat anything and everything, no matter whether it is worth eating or not, are ascetics; they alone are perfect men and they are worth adoring. People, who are of maleficent conduct are held in great esteem and they alone are worthy of honor. Even so they alone who are babblers in thought, word and deed are orators, dominated by women, dear reviewer, all men are dancing to their tune like a monkey controlled by its trainer. All men are given over to sensuality and greed and irascible too, and are hostile to Absolute and founder of science Vedas as well as to the saints. Unfortunate wives desert their accomplished and handsome husband and bestow their heart on a paramour. Wives having their husband alive have no ornament on their person, while widows are adorning themselves in the latest style. The disciple and the preceptor severally resemble a deaf man and a blind man: the one would not listen, while the other cannot see. A spiritual guide who robs his disciple of money but fails to rid him of his sorrow is cast into a terrible hell. Parents call their children and teach them such religion as may fill their belly. Men and women talk of nothing else than the Knowledge of Brahm/Absolute; while in their greed they would kill a Brahman or, for the matter of that, even their own spiritual guide for the sake of a single shell. They alone who are covetous of another's wife and are clever at wiles and steeped in delusion, malice and worldly attachment are enlightened men swearing by the identity of the individual soul with Brahma. Such is the practice I have seen in this age. Doomed themselves, such people bring ruin even to those rare souls who tread the path of virtue.

All men follow a course of conduct of their own imagination; the endless variety of wrongdoing cannot be described in words. Men perpetrate sins and reap suffering terror, disease, sorrow and desolation. Overcome by delusion they walk not in the path of Devotion, conjoined with dispassion and wisdom's path which has the approval of the Vedas and invent diverse creeds of their own. The so-called recluses build themselves houses and furnish them at considerable expense; dispassion is no more to be seen in them, the same having been wiped out by their sensuality. Men drive out a well-born and virtuous wife and bring home some servant-girl, casting to the winds all good usage. Sons respect their father and mother only so long as they have not seen the face of their wife. From the time they take a fancy to their wife's kinsfolk they begin to look upon their own people as their enemies. Kings get addicted to sin and cease to have anything to do with doctrine. Men practice Japa (the muttering of prayers), austere, penance and charity, perform sacrifices and undertake sacred vows with some unholy motive. Women have no ornament except their tresses and have an enormous appetite. Though miserable for want of money, they are rich in attachment of various kinds. Though hankering after happiness they love not piety, stupid as they are. Though they are poor in wits, their mind is hardened and knows no tenderness. As for men, they are tormented with diseases and find no enjoyment anywhere.

They are conceited and contend with others without any rhyme or reason. Men's life is short, extending to not 
more than fifty to sixty years; yet in their pride they reckon on surviving the end of creation. The age of Kali has driven men mad: no one respects the sanctity even of one's sister or daughter. There is no contentment, nor discernment, nor composure. People of all classes, whether high or low, have taken to begging. Envy, harsh words and covetousness are rampant; while evenness of mind is absent. People are all smitten with bereavement and deep sorrow. The duties and rules of conduct prescribed for the four orders of society and stages in life are neglected. Self-control, charity, compassion and wisdom disappear; while stupidity and fraud multiply to a large extent. Men and women all pamper their body; while slanderers are diffused all over the world. Please understand it: the age is a storehouse of impurities and vices. Is there any remedy available in whole world to eradicate these traits? Can it be possible? There are so many potential questions are resolved In this presidential address, I am about to describe systematically and final emancipation is possible in this age without any exertion, if understood with wisdom, devotion and faith. The theory of mineness is in need of immediate change into evenness. Wasting of human and money power in Nescience require stopping. A systemic understanding about the reality will be helpful towards the establishment of peace.

\section{Role of Spiritualism in Health}

In a human body, the soul is a particle of the Divinity, Immortal and Conscious untainted by deluding potency and blissful by nature. Spiritualism is considered as the advanced science of spirit, which is concerned with the higher aspect of life. It is synonymous with religion and philosophy, usually considered beyond the realm of modern physical sciences. It carries different meaning from one part of the globe to the other part; and from one group of persons to the other. But everyone seems to agree that the spiritual aspect of one's life is intimately related to development of brain efficiency and mental processes i.e. mind; and affects the psychic functions of an individual. To me, the spirituality in all its aspects seems to be a function of functioning human brain. My knowledge of life science is enough deep for understanding of human mind and the phenomena of our universe. Dwelling about complete health, piety and peace problems are my concern, as much yours, to what affects the mind or the psyche of a person. As we go through the annals of history of mankind on our planet, it appears that the spiritualism in its various forms had been in existence since eternity and what happens after one's death had been the query in every mind. Reports and writings of prophecies and precognition, apparitions, thought, transference and clairvoyance keeps on bogging our head and make us feel that, we the scientists and healers of mind still do not understand the human mind in all its propensity and potentialities. Psychobiophysics \& Psychobiology does not find any distinct place in our curriculum of medical studies.

If we have to believe the spiritualism and various psychic phenomena put on record, there exists no doubt that it consists of a good body of facts, and spiritualism is an oldest science out of focus from the present day scientific mind. Scanning the literature, it is revealed that in the Western Countries during the last few centuries spiritualism was rampant. It is believed to do something with supernatural \& continuity of life after death. The possibility of communication between dead and living through the agency of a medium was well recognized and documented (Podmore - 1910). A medium is a person with unusual sensitivity which enables him to be readily controlled by the disembodied spirits. A medium formed a link between dead and living. What qualified a person to be the mouth piece of supernatural was not known. Besides, spiritualist was known to carry certain power in varying proportion thorough which they were able to perceive and communicate beyond time and space. They were able to exhibit certain physical manifestations such as materialization of spirit form, apportion i.e. production of material objects by supposedly occult means at a spiritualistic sense, moving of inanimate objects without any visible contact and performing other mystic feats like going to trance state, thought reading, crystal gazing, levitation i.e. rising and floating in air, automatic writing and slate writing etc.

The spiritualism by many was considered to be the act and influence of spirits of the deceased. The witchcraft, demonic possession, poltergeist disturbances and animal magnetism was considered to be part of it. The concept of animal magnetism was first described by the illustrious famous physician Paracelisus. But, it was Franz Antoine Mesmer in 1776, who united the two phases of this magnetic philosophy. As per which, a force radiate from every substance, animate as well inanimate including heavenly bodies i.e. planets and human beings, making them to interact. The Mesmer's animal magnetism was utilized to induce hypnotic trance. The term Mesmerism came in vogue and hypnotism which was a part of spiritualism was used as a treatment modality for some diseases. Mesmerism was later replaced by the new doctrine of suggestion, advanced by a Paris physician Alexander Bertrand in 1823. The doctrine of suggestion, as we all know, still holds good in the present day practice of Psychiatry. The hypnosis still forms a modality for treatment for some diseases. Recchenbeck in 1845 demonstrated the existence of an emanation called Odicforce radiating from every substance which can be seen by the clairvoyants. The German investigators Jung and other recorded the phenomenon of clairvoyants in their somnambulism. In France, Planchelte in 1853 invented a simple instrument giving it his name and used it for spirit communication. Allen Kardec (1898) attributed this phenomenon as inferior phase of spiritualism and expressed belief in reincarnation. As the wave of this spiritualism swept in Europe and America during the last century, many people started practicing trickeries and frauds.

This brought under clouds the gentility of those reports. The rationalists disbelieved these so called spiritualistic phenomena but were unable to refute them on many occasions. I consider those people as a dull witted and hostile for Absolute. To investigate those claims the Society for Psychical Research was established in 1882 in UK; which made the first organized and united attempt to study those spiritualistic claims in a purely scientific, impartial and unbiased manner, avoiding cautiously any prejudice and preconceived approach. They called them psychical phenomenon and could detect great deal of 
fraud in mediumistic performance like slate writing and other physical manifestations. About 17,000 cases of apparitions of the dead and living were collected and studied. The apparitions coinciding with death or other crisis were found to occur much in excess than that could be ascribed to chance alone, which testified the occurrence of apparition \& accredited the phenomena of telepathy \& thought transference. But the reports about telergic power were a few. Similar psychical phenomena and mystic feats are reported from India and other countries also. I appreciate those efforts, but simultaneously would like to report that people of above mentioned organization as a slave of deluding potency. I also like to state that one can behead if I will be found wrong at any level. I could not ask for any pardon. Thus, its my humble request to review the next with great attention, devotion and wisdom.

While I sat in transcendent state of mind after about 20 years 04 month 15 days exile in the world-woods for a period of 40 days, analyzed various critical questions like: Can there be anger without duality or duality without ignorance? Can an individual soul, dull, finite and subject to deluding potency, ever be on a par with Absolute? Can suffering ensue from solicitude for other's well-being? Can anyone possessing the philosopher's stone suffer from want any longer? Can the malevolent be free from anxiety? Can the sensualist escape obloquy? Can one's posterity survive even though one has persecuted the pious souls? Can one continue to perform actions (with attachment) even after attaining Self-Realization? Has anyone acquired sound wisdom while living in the company of the vicious? Can an adulterer attain a happy destiny? Can those who have realized God fall again into the ocean of transmigration? Can the revilers of Absolute be ever happy? Can a kingdom stand without the knowledge of statecraft? Can sins persist even after one has commenced narrating supreme's exploits with complete devotion? Can one enjoy sacred renown without religious merit and can anyone earn a bad reputation without a sin? Is there any gain as valuable as Devotion, which is glorified alike by saints as well as by the Vedas and Puranas? Is there any loss in the world as grievous as that of the man who fails to follow and adore Absolute even after obtaining a human body? Is there any other sin so bad as backbiting or any virtue as great as compassion, dear people of globe? In this way I mentally advanced numberless arguments in my favor and took the charge to eradicate the sins from the world with reverence. During the course of my study, I have developed the medicine for vitiligo using Ayurvedic ingredients that has complete power to eradicate white patches if used under the devotional state of mind. This opens a area for the genes regulating the synthesis of melanin and death of melanocytes. Video.1 revealed the development of melanin on my own body.

\subsection{Effect of the Gems of Devotion on Human Health}

Since Jan 18-Feb 27, 2014, I have been under meditation and transcend state of mind. I found almost everyone (man and woman) is given over to sin and they are slumbering in the night of delusion. The world is steeped in lust, anger, arrogance and greed only. Pulling out people from such demon traits by spirit and devotion would be my first priority as a true thinker. Dear reviewer, read carefully about virtues of devotion, which has been likened to a jewel. The effulgence from gem of devotion sheds its radiance day and night. He, in whose mind, such a jewel abides is not haunted by poverty in the shade of infatuation. No blast of greed can ever extinguish this light, which dispels the overpowering gloom of ignorance and the swarms of moths (in the shape of vanity etc.,). It keeps away from it in a mood of frustration and anxiety. Vicious propensities like lust dare not approach him in whose pure mind the gem of Devotion abides. For those venom could be transformed into ambrosia (Pandey R, 2004) and enemies turn into friends; nobody can attain happiness without this jewel. Again, people never attacked by the terrible mental diseases from which all living beings are grievously suffering. All, in whose heart the gem of Devotion abides cannot have the least woe even in a dream. They alone are paragons of wisdom in this world; who spare no pains to secure this gem. Although this jewel is manifest in the world, none can find it without the development of evenness and love for Absolute. In our ancient science like Vedas and Puranas and the stories of Lord, many glorious mines located in their midst has been represented. The saints are the expert mineralogists and their penetrating intellect, the pick axe; while spiritual wisdom and dispassion are the two eyes. Any individual, who looks for it with faith, succeeds in discovering the gem of Devotion, a mine of all blessings. Realizing this whoever cultivates the fellowship of saints finds Devotion to Absolute (Tulasidasa G 1566).

\subsection{Role of Telepathy in Human Health}

Telepathy means intercommunication between one brain and another brain by means other than that of the ordinary sense channels. It has a bearing on all psychic phenomena. Many cases are on record, where most vivid impressions have been transmitted from a distance. It is believed that telepathic communication goes direct from one mind to another irrespective of the distance. The trivial circumstances can be transmitted to a percipient near, at a hand, while as a rule only the more intense \& violent impressions are received from a distance. The theory of thought transference is no new one. It is said to be a daughter of the hoary science of astrology. Podmore (1902) was the exponent of theory of telepathy. The telepathy experiments were conducted long back by Sidgmickin in 1889-91. Since that time onward increasing body of scientific opinion is developing favoring the presence of this surmised mode of communication, which may be within a reasonable distance of becoming an acknowledged fact (Lewis Spence, 1988). The mechanism of telepathy is generally supposed, so far, to be in the form of yet unknown etherical vibrations or "Brain Waves". The study of coincidental hallucination (i.e. hallucinatory apparitions) coinciding the death of a person represented or with some other crisis in one's life are also attributed to this phenomenon of telepathy.

\subsection{Role of Clairvoyance on Human Health}

A term denoting the supposed supernormal faculty of seeing person and events which are distant in time and place and of which no knowledge can reach to the seers through the normal sense channels. Three types of 
clairvoyance are: 1 . Retrocognition - perception of past 2. Premonition - perception of future events 3. Perception contemporary events happening at a distance, outside the range of normal vision. What telepathy is in auditory modality, clairvoyance is in visual modality. Based on the clairvoyant experiences the great prophecies have been made. To illustrate this, I shall quote a best -seller widely acclaimed. To explain these prophecies, Erika Cheethan (1975) has made some unbelievable observations. To quote him, "The modern disciples of Einstein recognizes nothing but an eternal present which was also what the ancient mystic believed. If the future exists already then precognition is a fact. The whole trend of advance knowledge is to place the laws of physics in a four dimensional continuum, that is, the eternal present. If this is so, then past, present and future exists simultaneously. Perhaps it is only our unconsciousness in form arrogance of mineness that moves?" Ladies and gentleman, it appears a very absolute concept that time is static and unconsciousness is moving. The philosophy is real and, quite a thought provoking one. It may mean similar to, as with the primitive man who observed the moving sun and believed that earth is static or like a passenger in a train who seeing the moving horizon forget for a while the speeding train. We know that both sun and earth are in motion. So it may not be improper if it is to be believed that like sun and earth in motion, it is the time as well our consciousness both are in relative motion maintaining a fixed proportion or ratio.

\subsection{Effect of Trance State on Development of Mind}

Trance state is found to occur in mystics \& men of proven spiritual attainment other than those suffering from psychomotor seizure and in state of possession. But the quality of experience differs. The stage of samadhi or eternal bliss which is also called state of super consciousness is not definitely devoid of dissociation. We in psychiatry understand the dissociation, meaning the disruption of normal integration of cognition, affect, behavior, sensation and identity. This may range from day dreaming and transient lapses in attention through phenomenon to pathological failures (Atchison \& Mc Farlane, 1994), which are well known to all of us. But very little work is done to know the psycho physical basis and the psycho physiological and biochemical correlates during the process of dissociation. My study revealed that under trance state of brain, one can wiped out all the impurities (Ignorance) of body system.

\section{The Concept of Reincarnation}

Reincarnation means entry of a soul into another body after death. The doctrine of reincarnation is avowed in a large part of Asia and particularly by Vedanta philosophy and the various other religious philosophy like Buddhism and Jainism. Its evidences are found in Greek thought, Zoroastrian scriptures, and others. Existence after death presupposes existence before birth. As per Vedanta philosophy and other eastern thoughts, doctrine of reincarnation is associated with the doctrine of deeds (Karma). The man is reborn for the sake of his Karma and attainment of their fulfillment liberates the soul from the chain that ties him to the wheel of birth and rebirth (Vivekanand Ji). Similar thoughts are shared by the Scottish philosopher and historian David Hume. Theosophist believes in astral form of body called astral body which parts away from the physical body on death and moves in astral world. The astral philosophy essentially remains same as that of Vedanta philosophy on this subject with some minor differences. I shall have gone into the details on this subject, which is in the realm of religion and philosophy and found the science at the level of bank of wisdom only. However, it will be worth mentioning here that the study of reincarnation type of cases is gaining recognition by the scientific communities, world over and claims of children who say that they remember previous lives have been under investigation in many cultures both in east as well in the west.

The work done at NIMHANS at Bangalore in India during last few decades is worthy of appreciation. Thousands of cases investigated so far by different workers around the globe (Stevenson 1974, 75) and analysis of that date had shown certain common features which points towards the universality and some authenticity of this phenomenon. (Pascricha \& Stevenson 1977, Pascricha et al 1980, Pascricha 1990). The investigation of the phenomenon of survival of bodily death by Moody (1975) as reported in his book "Life after life" is also worth acknowledging. If that is so, then it appears that folklore, mythology and religious philosophy, which is shared universally since ancient time, has definitely above scientific wisdom. It remains to the present day scientific community to work out the hightech modality and develop equipment to seize, once again, the stark reality. I am here eveready to direct the areas to resolve the potency of deluding power.

\subsection{Spiritualism in India}

The spiritualism in India and many eastern countries is recognized as a way of life with eternal joy and bliss beyond the precinct of sense pleasures. It is identified with something super conscious, supernatural and towards divinity. Spiritual inspirations are considered as a rare blessing and it is not only believed that through the path of spiritualism a man attains perfection and ultimate desire fulfillment is possible. The spiritual experiences, not only brings the knowledge of super consciousness but also solves the problem of unconscious mind. The spiritual joy is considered more super than the intellectual joy which, in turn, is higher than the sense pleasures; as it does not lead to frustration, \& disappointment but provide ultimate satisfaction (Yatiswamanda 1979). The Indian Vedanta philosophy describes four approaches for making advance in the spiritual life namely Karma Yoga, Raja Yoga, Bhakti Yoga \& Gnana Yoga. Out of these four yogas Raja yoga shows the path of meditation, which may be of direct concern to all the people around the globe. Patanjali, the great sage, was the chief exponent of this yoga. He considered eight stages called Ashtanga Yoga. 1. Yama Moral conduct encompassing truthfulness, non violence, chastity, control of greed, non covetousness \& non dependence on others. 2. Niyama - Self discipline contentment \& cleanliness. 3. Asna - Postural exercises 4. Pranayam - Control of Prana (subtle life energy) by 
regulating breathing 5. Pratiyahara - Withdrawal of senses from the external world \& introspection 6. Dharna Concentration 7. Dhyana - Meditation 8. Samadhi - Super conscious experience. To attain super conscious state one is required to pass through first seven stages. Yogas had been a subject of great research. It is found to be of positive help in stress management and relief of anxiety and mental tension (Vahia 1973, Sahay 1982, Selvamurthy 1983, De Souza 1984). Dhyana or meditation is an important stage through which depending upon the state of achievement a person enters into the stage of samadhi a state of blissful trance (A state of super consciousness and supreme awareness where the mind transcends). The various psychic phenomena described earlier are the manifestations of the psychic powers one attains during the process of attainment of this state of super consciousness. They have been described by the different persons who had spiritual attainment. Meditations stabilize the autonomic nervous system and make a person withstand environmental stresses better (Orme Johnson 1973; Venkoba Rao 1978). EEG recordings during meditation had shown better synchrony of the alpha and beta frequencies (Wool Folk 1975, west 1979). There are many methods of meditations viz. Transcendental meditation, Vipasana meditation, Prekshyadhyan and others. A Mahapurush or the Guru guides his disciple in the finer approach at sensitive stages. Vipasana meditation is an ancient Indian method of meditation which was followed in east \& south east Asian countries since the time of Gautama Budha. The method involves observance of Sila (Moral Conduct), Anapana (Awareness of Breathing), Vedna (Feeling of sensation). Another ancient method Prekshyadhyan is taken from Jainism. It is reported to lead one to spiritual path, reduces $\&$ relieves the various tensions of mind and improves the physical \& mental health of the person practicing it regularly. As per Bhamgra (1990), spiritual dimension of health pervades all other dimensions of health i.e. physical, mental \& social. The Vipasana meditation may also help in deaddiction (Scholz, 1990). For that purpose I may add, any type of meditation if followed regularly may help in de-addiction as they all advocated the similar prerequisites and practices. I shall not go in to the details of yoga \& meditation here as they are aptly described by their proponents. Mysterious Energy Field, a Psychphysiologists had been of the view that there is something like bioenergy. Recognizing the animal magnetic force of Mesmer, Odic force of Reichenback, N rays of Blondot, Bioplasmic energy of Soviet scientists \& psychotronic energy described by Czech scientists, most of them are in agreement regarding the general characteristic of this energy, (Schul \&. Petft, 1975), that do not abide by the various physical laws. The experiments with psychotronic generators and with Kirlian photography are being conducted to understand this human psychic force and to identify it under the known laws of physics. Whatever it may be, people around the globe do not yet known what it is? Neither all are able to accept it, nor refute the claim. I am here to address all the real fact to all the world's men of wisdom. There is a saying worth quoting here that is "All that glitters is not gold". I too, like most of you, firmly believe in it. But unless there is existence of gold somewhere no one would be talking about its glitter. Hence, ladies \& gentleman, you would like to agree with me that even if a grain of truth is found in all that what we have deliberated upon so far, it is worth continuing to know further.

Back pain is a very common complaint. According to the Mayo Clinic, USA, approximately $80 \%$ of all Americans will have low back pain at least once in their lives. In India the risk of cervical, backache, arthritis, sciatica, gastric, sugar, leukoria, headaches, migraine, waist pain, muscles pain and blood pressure are increasing day by day. The factors, causing such a painful diseases are stress, pregnancy, sedentary lifestyle, ageing, anxiety, depression, gender (back pain is more common among females than males), obesity/overweight, smoking, strenuous physical exercise and physical work. Under these environments Medical treatment for said diseases is not much successful. Modern yoga has ability to cure all the said diseases. About 10,000 people have been cured in plenty of camp (Dr. Babu Ram Yadav).

\subsection{Cybernetics}

The science of system control and communication in animal and human brain had provided many clues about electrophysiological and biophysical functioning of brain. These clues provided the possibility of developing the artificial intelligence which led to the development of present day computer science. Today we know how helpful the computers are in every walk of our life. When we look back and think about human brain and its potentialities it becomes apparent that it is a very magnificent and highly developed, rather evolved, electromagnetic organ. We can identify in it presence of various electromagnetic gadgetry developed by man. If we look at the Cybernetics in a reverse way the visual perception right from retina to occipital cortex will appear a beautiful and very efficient close circuit TV camera \& TV set; our ears and auditory perception from ear drum through auditory nerve to the cortical area are similar to the telephonic system, memory is like a tape recorder, calculating faculty like a calculator, intellectual faculty is alike to a computer in the brain. If that is so, then, what is left out or missing is a radio. It is difficult to believe that radio which was made by man much before the other gadgets would not exist in a human brain.

\subsection{Radio Phenomenon in Human Brain}

When acknowledged as a scientific fact it would be able to solve and explain many of the puzzles. It may provide better understanding \& acceptance of various occult and spiritual phenomenon. The evidence in its favor is already provided by the various observations made by different groups working with ESP i.e. extra sensory perception and thought transference or telepathy. Once the radio phenomenon in human brain is proved it will be easy to understand the phenomenon of clairvoyance also. By radio phenomenon I mean communication beyond time \& space by means other than known physical contacts or through speaking, reading \& writing. I have called brain a most highly evolved electromagnetic organ. The structure of this highly evolved organ is not a physical one as that of manmade gadgetry, but is a biological structure. As we know the biological material is self developing, self evolving, self reproducing, capable of training or learning \& self repairing one. It is 
interdependent to the systems \& body it belongs to. Its survival and functioning depends on the genetic coding it received and oxygen \& nutrition it is supplied with for its metabolic needs. Each neuron, the functioning unit of the brain is a very sophisticated high tech workshop in itself, dealing not only with various molecules and atoms, but subatomic particles as well, and functions in a very precise precoded manner. We must also understand that the laws of physics remain same for both the inanimate as well as animates, but they are cast into a biological mould for animates. Radio phenomenon seems to be a dormant faculty of the brain which could be activated \& developed with certain practices, which, I think Yogis \& spiritual persons are better qualified for. Its experimental demonstration become difficult as it may need live human brain where this phenomenon is activated and already developed. However certain experiments conducted on human volunteers at the yoga lab of Defence Physiological Laboratory at Delhi tor the study of Agnihotra, a vedic rutual tor enhancing tranquillity by Selvamurthy (1989), revealed startling findings. Selvamurthy attributed these results to the effects of mantras. Golechha et al (1987 \& 1991) used Agnihotra procedure as an adjunct in the treatment of drug abuse and alcoholism. They found a clinically demonstrable positive effect of enhanced tranquility in these subjects. The effect was of the degree that counterbalanced the urge for drugs and alcohol. It was hypothesized that this positive effect could have been due to the changes, in the electromagnetic milieu (EMM) surrounding the subjects, which was brought about by Agnihotra. Due to lighting of the fire in the Agnihotra copper pot there occurs emanation of some energy which might have enhanced or amplified the EMM prevailing at the prescribed timing of sunrise and sunset. The cosmic rhythm of EMM prevailing at the time of sunrise and sunset, are known to be mind soothing. The finding of delta wave suppression and alpha activation as recorded on computerised EEG during Agnihotra in the frontal leads indicate that there exist some mode of non contact communication between Agnihotra energy pot and neuronal group producing the fcEG effect.This may be through the eminence "certain electromagnetic waves whose frequency and amplitude is not known and requires" be ascertained. Once ascertained this may help to break some ice about a neurophysiological phenomenon of finding a neuronal group in frontal/ prefrontal area responding to this cordless wave form of communication, which may come to our rescue for demonstrating and acknowledging the much talked about radio phenomenon in human brain. And, the further dedicated research may dispel the various myths about telepathy and thought transference and may throw better light on the occult phenomenon. Already a sea of scientific data is getting accumulated regarding effect of geomagnetic field on the brain which I shall touch upon shortly.

\subsection{Electromagnetic Milieu (EMM)}

When we have a global look at the spectrum of electromagnetic field one may get flabbergasted for a while, and cannot save himself from pondering on the mythological concept of power (shakti). The spectrum of energy i.e. the electromagnetic waves could be divided into the two broad groups. The ionising group of electromagntic waves encompassing nuclear radiation, $\mathrm{X}$ rays, gamma and cosmic rays of high frequency. They carry enough energy to project electrons out of their orbit. Whereas non ionising electromagnetic waves are of low frequency which includes ultraviolet, visible spectrum VIBGYOR, infrared, microwaves, lasers, short waves, middle waves and long waves used in radio, TV and space communication i.e. satellite and inter planetary communication. It will not be wrong if I say that we are surrounded and engulfed not by the shades of light \& darkness or heat or cold but by the different frequencies and amplitude of perceptible and imperceptible energy form of electromagnetic miliue all throughout our life, where ever we are and in both states of waking and sleep. Being a highly evolved and sophisticated electromagnetic organ, it is likely to respond to the changes in the surrounding electromagnetic milieu whose rhythm keeps on altering depending upon the geomagnetic field and solar cosmic radiation and eminence from other similar sources.

\subsection{Mental Health and Neurophysiological Correlates of EMM}

The biological effects of various radiations are known to us to a great extent. Case reports of effects of microwave producing psychic changes are on record (Wurster et al, 1988), the seasonal affective disorder is a well documented and extensively studied entity. The effect of light therapy is also well accepted (Ronald Kay, 1994). The pineal gland has been shown to be sensitive to changes in the magnetic field exposure in laboratory animals. The alteration in geomagnetic field is associated with decreased serotonin Nacetyl transference activity (Welker et al, 1983), decreased pincalocyte electrical activity (Semm et al, 1980) and decreased melatonic synthesis (Olcese et al, 1985). The pulsed field, at geomagnetic field strengths, increases nor-adrenaline secretion by more than $25 \%$ in cloned neuronal cells in vitro (Dixey \& Rein, 1982). Our retinal rods, which are the magneto receptors, arc responsive to low energy changes in geomagnetic field (Olcese et al, 1985), which may also explain the effects of Agnihotra on human mind. The solar flare emanating charged particles produces geomagnetic storms accounting for seasonal variations in the incidence of depression. It is also shown that in vivo, magnetic fields may affect pineal function via the complex adrenergic system which also provide main enervation to pineal gland (Vanecek 1985, Ebadi \& Covitrapong, 1986). It is now established that low energy geomagnetic field decreases the hydrophobic character of the cell membrane leading to changes in its permeability and enhance calcium channel activity (Karaliers \& Ossenkopp, 19871988). Persingcrand Lcvesque (1983) in their study described upto 4(Y7c variation in daily mood of the subjects, which can be accounted for by the daily mean index of geomagnetic disturbances. A positive correlation was found in solar radio flux levels and indices of geomagnetic ionosphere disturbances with monthly total Psychiatric admission (Raps et al. 1991). Thus, researchers find that the changes in the electromagnetic milieu surrounding us have great effect on our mood, behavior and psyche. Whether this provides any answer for the various Psychical or spiritual phenomenon already 
discussed remains to be seen. In addition to the available neuro-endocrinal \& neurophysiology investigations, advances made through studies like positron emission tomography (PET), single Photon emission tomography (SPECT), Nuclear magnetic resonance (NMR) and functional magnetic resonance imaging spectroscopy, it is now possible to probe functional neuroanatomy of human emotions both in normal state as well during mentally disordered state (George et al, 1995). The change in regional cerebral blood flow and other metabolic parameters have opened the door for more objective study of neural substrate involved in human emotional behavior. Through this innovation it is now possible to map brain activity associated with emotion (Robinson, 1995) and imaging the mind and functional brain is not a fore fetched thing (Cohen et al, 1995). These advances associated with electro physiological study through computerized EEG evoked potential studies and other means may be of great importance for the study of various psycho physiological and psycho physical changes occurring in the brain and thus make it possible to study spiritualism further in all its dimensions. These efforts may be further supplemented by the physicist who are better knowledged about geomagnetic phenomena and electromagnetic waves and contribute to the concept of electromagnetic milieu affecting human brain. They may also help to identify the spectra which may act as brain waves during thought transference of telepathy.

\section{Discussion and Conclusion}

I found that the field of spiritualism, encompassing various psychical and super psychical phenomena is of direct concern to not only psychiatrists, psychologists and neuro-scientists but to the whole mankind. Better understanding of various psycho physical phenomena and role of electromagnetic milieu in the psychophysiology of thought, emotions and behavior may provide newer avenues to peep into the phenomenology of various psychiatric illnesses. "Time is stagnant only the waves of Lust, Anger, Greed, Arrogance, Jealous and Infatuation are flowing throughout the universe." The knowledge of wisdom can be gained only by dispassion and true preceptor. The knowledge gained with further research in these directions may lead to change in the attitude of mankind towards real life. Which may be of ultimate benefit to all and a balanced approach equalizing materialism with spiritualism, may provide a more fruitful \& meaningful life for all of humanity. Devotion to Absolute would provide the real joy of life. Health, piety and peace are possible by spirit, ayurveda, modern yoga \& science. In brief, there are three evils most formidable of all lust, anger and greed. In an instant they distract the mind of hermits who are the very repositories of wisdom. The weapons of greed are desire and hypocrisy, of lust naught but woman; while anger's weapon is harsh speech: I so declare after my deep thought. Anger, lust, greed, pride and delusion, all these get eliminated through the devotion in Absolute. He who wins the favor of that divine player is never deluded by his jugglery. I like to tell the world my own realization; the only element of reality is true LOVE for all in this universe considering the fact that all are made up with the same elements. Saint's are rounding around the globe whose heart devoid of pride and infatuation, the wise shake off the possessive. The fruit of one's meritorious deeds appears at the appointed time (neither sooner nor later). Only rare soul comes to develop devotion to Absolute with thought, word and deed. Eradication of impurities from materialistic body will wipe out all the sins and people will enjoy the happy and peaceful life as a real gain of human birth. Based on EVENNESS theory, I have developed the following four objectives of my next $20 \mathrm{y}$ of life are as follows; (A) Eradication of the root cause of diseases of mind and body from the world by Gnosis of modern science, Ayurveda, Yoga, Devotion and Spirit (B) Treatment of Arthritis, Cervical, Backache, Sciatica, Gastric, Sugar, Leukoria, Headaches, Migraine, Waist Pain and Muscles Pain by modern yoga, (C) Foundation for the doctrine of Piety and Human life, (D) Establishment of Sub-centre and institutions in all the countries around the globe. The mysterious potency of deluding power could be resolve from this center. As such there is a pressing need to address world for the ultimate human welfare in the form of happy and peaceful life. Which is under the control of mind and not obeying the commands of the soul, thus tremendous grief appeared in whole universe. All seem to be self murderer. Thus, I encourage all existing Seers, Saints, Sages, Adepts, Preceptors, Theosophists, Chiefs of the World Organizations, Vice-chancellors of Universities, Director, Scientist, Professors, Governing body, Men of Religions and Philosophy to answer me 'Where is duality? As such this does not exist. Spread the evenness theory and eradicate the basic six impurities as described. The scientific evident could be generated and as foolproof scientific understanding of the phenomenon is immediate need to develop that was still out of the sight. Considering the grief of whole universe, I have developed the devises using the existing knowledge of Spirit, Yoga, Ayurveda and Science to untie the knot, and reframe the universe by providing Health; Piety \& Peace form this world center. There are plenty of research waiting for pure servant, who is absolutely pure from thought, word and deed. In case, word will provide me opportunity, Twenty years is more than sufficient for reverting the universe into happiness and peace.

\section{Acknowledgement}

I sincerely acknowledge and thank the novel adept of Sri Ram Charit Manasa, Sh. Lallan Dubey, Vice president and Assistant Director, World Health Piety and Peace Center for his providing all the facilities. I consider him 'A Man of Wisdom \& Devotion' on this earth.

\section{References}

[1] Atchison M \& Mc Farlane A C (1994), "A review of dissociation \& dissociative disorder", Australian \& New Zealand Journal Psychiatry 28: 591-599.

[2] Allan Kardec (1898), "The book of spirits", Kegen Paul, New York. Bhamgara M M (1990), " Spiritual dimension of health - the neglected dimension" Peoccdings of international seminar on Vinassana Meditation and health, Vipassana research iastitute,Dhammagiri, Igatpuri - 422 403, Distt Nasik (India).

[3] Bill Schul \& Ed Pettit (1975), "The secret power of pyramids", Fawcett Gold Medal, New York, 43-45. 
[4] Choudhury M, Pandey RS, Clemens DL, Davis JW, Lim RW, Shukla SD (2011): Knockdown of gen5 histone acetyltransferase diminishes ethanol induced histone acetylation and affects differential expression of genes in human hepatoma cells. Alcohol; 45: 311-324.

[5] Cohen B M,Renshew P E, Yurgelun D (1995), "Imaging the mind: Magnetic resonance spectroscopy and functional brain imaging", American Journal Psychiatry, 152-155, 655-658.

[6] Desousa Alan, Desousa D A (1984), "Yoga Meditation and Mysticism", Psychiatry in India, Bhalani Book Depot, Bombay, 21-52.

[7] David Hume, "Immortality of the soul", George Routledge and sons Ltd, London, 424-427.

[8] Erika Cheetham (1975), "The prophecies of Nostradamus, Corgi Books London, 15.

[9] Gurnay E, Myers FWH and Podmore F (1918), "Phantasms of the living", Edited and Adridged by Mrs Henry Sidgwick, Kegan Paul (Dotton, New York).

[10] George M S, Ketter T A, Parekh P I, Horenitz B, Herscovtch P, Post R M (1995), "Brain activity during transient sadness and happiness in healthy women", American Journal of Psyciatry, 152(3) : 341-351.

[11] Goodrich Freer (1982), "Essay in psychical research proceeding and journal of the society for psychical research", London, UK.

[12] Golechlia G R, Deshpande M, Sethi I C, Singh R A (1987), "Agnihotra a useful adjunct in the recovery of a resistant demotivated smack addict", Indian Journal Psychiatry, 29 (3), 247-252.

[13] Golechha G R, Sethi 1 C, Deshpande M, Usha Rani (1991), "Agnihotra in the treatment of alcoholism", Indian Journal Psychiatry, 33(1): 44-47.

[14] Kay R W (1994), "Geomagnetic storms associated with incident of depression as measured by hospital admission", Brit. Journal Psychiatry, 164,403-409.

[15] Lewis Spence (1988), "Psychical research, The encyclopedia of the occult", Bracken Books London. 330-332.

[16] Moody Raymond A , Ir (1975), "Life after life, the investigation of a phenomenon - survival of the bodily death", Walker \& Company, New York.

[17] Orme Johnson D W (1973), "Autonomic stability and transcendental meditation: Psychosomat medi", 35, 341.

[18] Pandey RS: Discovery of novel antisense-oligos (ASOs) for prevention of Spinal Muscular Atrophy caused by pesticides by genetic mutation. National Conference on Systemic Approach in Implementation and Resource-Saving Technologies in Food-Crop Production: Prerequisite for Eco-Balancing. November 23-24, 2013 Varanasi: Abstract book pp.5

[19] Pandey RS: Gene network and canonical pathways analysis in human hepatoma cell VA-13 to study alcohol metabolism and signaling pathways: a microarray study. Scope of translational researches in ayurvedic medicine. 2013: 01-16

[20] Pascricha S \& Stevenson I (1977), "Three cases of reincarnation type in India", Indian Journal of Psychiatry, 19: 36 - 42.

[21] Pascricha S \& Stevenson (1979), "A partly independent replication of investigation of cases, suggestive of reincarnation", Europian Journal Parapsychology, 3 : 51-65.
[22] Pascricha S, Murthy V N, \& Murthy H N (1980), "The scientific investigation of rebirth cases: Problem of field work $\&$ analysis of data", Indian Journal Psychiatry, 22: 206-210.

[23] Potdar M M (1990), "Agnihotra for equilibrium of nature \& enhancement of human life", Instt. for studies in Vedic sciences, Shivpuri, Akalkot-413 216 (India).

[24] Robinson R G (1995), "Mapping brain activity associated with emotion", Editorial, American Journal of Psychiatry, 152 (3), 327329.

[25] Gerhard. S (1990), "The significance of the dialectic of physical sensation and craving for the drug addiction, a new addiction theory and perceptives of intervention", Proceedings of International seminar on Vipassana research Institute, Dhammagiri, Igatpuri - 422403 (India).

[26] Sahay B K, Sadasivudu, RAmanda Yogi, Basharacharyulu C, Raju P S, Madhavi S, Reddy M V, Anupamma N, Murthy K JR (1982), "Biochemical parameter in normal volunteers before and during yogic practic", Indian Journal of Medical Research 75 (Suppl) : 144, 148.

[27] Schildkaraut S J, Hirshfeid A J, Morphy J M (1994), "Mind and mood in modern art II : Depressive disorder, spirituality and early death in the abstract expressionist artist of the New York School, American Journal Psychiatry, 151 (4), 482-488.

[28] Selvamurthy, Nayar WHS, Joseph N T \& Joseph S (1983), "Physiological affects of yogic practice", NIMHANS Journal, 1, 71-80.

[29] Selvamurthy W, Deshpande M, Mukhopadhyay S, Ray U S, Thakur L, Anand J P (1989), "Physiological effects of mantras on mind \& body", Proceedings of conference on "Mantra Yoga", Defence Institute of Physiology \& Allied Sciences, Delhi-10.

[30] Stevenson I (1974), "Twenty cases suggestive of reincarnation", Charlottesvilla, University Press of Virginia.

[31] Stevenson I (1975), "cases of reincarnation type", Vol I, Ten cases in India, Charlotterville, University Press of Virginia.

[32] Singh NN, Shishimorova M, Cao LC, Gangwani L, Singh RN (2009). A short antisense oligonucleotide masking a unique intronic motif prevents skipping of a critical exon in spinal muscular atrophy. RNA Biol. 6: 341-50.

[33] Tulasidas G (1566), Sri Rama Charita Manasa. Ayodhyay India. Uttar kand: 1012-1015.

[34] Vahia N S, Doongaji, Jeste D R, Kapoor D V, Ardhapurkar S N, \& Ravindranath S (1973), Further experience with therapy based on concepts of Patanjali in the treatment of psychiatric disorders", Indian Journal Psychiatry, 13, 32.

[35] Venkobalao A (1978), "Psychiatric thoughts in ancient India", Presidential address Indian Journal Psychiatry, 20-107.

[36] West M (1979), "Meditation, A review", British Journal Psychiatry, 135, 457.

[37] Wool Folk R L (1975), Psycho physiological correlates of meditation", Archives of General Psychiatry, 32, 1326.

[38] Wurster K, Rubsaamen G, G Kas U Ikongr (1988), "The biological action of microwaves", Medical Corp International, 2, 43-46.

[39] Yatiswarananda (1979), "Meditation and spiritual life", Sh. Ramakrishana Ashram, Bangalore (India). 